\title{
Відмінності постурального балансу у пацієнтів з деформуючими дорсопатіями та болем у шийному відділі хребта після виконання аеробних динамічних вправ
}

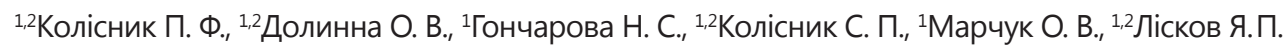 \\ ${ }^{1}$ Вінницький національний медичний університет імені М. І. Пирогова, м. Вінниця, Україна \\ ${ }^{2}$ Центр медичної реабілітації та спортивної медицини, м. Вінниця, Україна
}

Актуальність. Деформуючі дорсопатії (ДД) шийного відділу хребта (ШВХ) часто зустрічаються в структурі коморбідної патології, можуть супроводжуватись больовим синдромом та призводити до порушень постурального балансу (ПБ). Сабілометрія є одним із методів оцінки контролю балансу тіла. Доведений зв'язок між показниками стабілометричного аналізу та ризиком падінь. Вивчення порушень ПБ та можливостей їх корекції дозволить розробити програми реабілітації, знизити ризик травматизму та виникнення обмежень життєдіяльності у пацієнтів 3 ДД.

Мета: вивчити особливості ПБ у пацієнтів з ДД та болем у ШВХ до і після виконання АДВ.

Матеріали i методи. У дослідженні взяли участь 16 пацієнтів 3 ДД (середній вік 43,9 $\pm 10,0$ років), розділені на дві групи (основна - хворі з цервікалгією, група порівняння - без болю в ШВХ). ПБ оцінено за допомогою силової платформи до і після виконання АДВ. Стабілометрія виконувалась 3 візуальним контролем і закритими очима, в біподальній позиції, стоячи. ДД ШВХ діагностовано за даними рентгенографії. Статистичний аналіз отриманих даних проведено за допомогою програми SPSS. Різниця рівня ознак (відхилення тіла у сагітальній (ВСП) та фронтальній площинах (ВФП), середнє відхилення (СВ) від центру протягом часу дослідження - 30 секунд) в групах розрахована за допомогою U-критерію Манна Уїтні.

Результати та їх обговорення. Виявлена статистично значима різниця рівня ВСП між пацієнтами основної та контрольної груп незалежно від наявності візуального контролю, до та після АДВ. У фронтальній площині статистично значима різниця спостерігалась лише для показників, отриманих під час вимірювання після АДВ в позиції з закритими очима. СВ статистично значимо відрізнялось між групами незалежно від візуального контролю лише до АДВ. Результати представлені в таблиці 1.

Висновки. Встановлена достовірна різниця ВСП, ВФП та СВ до та після виконання АДВ, що може свідчити про позитивний вплив АДВ на ПБ у пацієнтів 3 ДД ШВХ 3 цервікалгією. Біль в ШВХ є фактором, що негативно впливає на ПБ, особливо в умовах відсутності візуального контролю. Обстежені, які не пред'являли скарг на біль у ШВХ, мали достовірно кращі показники ПБ перед виконанням АДВ та після фізичного навантаження. 
Таблиця 1. Показники стабілометрії у пацієнтів основної та контрольної груп у біподальній позиції з відкритими та закритими очима

\begin{tabular}{ccccc}
\hline \multirow{2}{*}{$\begin{array}{c}\text { Показники } \\
\text { стабілометрії }\end{array}$} & \multicolumn{2}{c}{ В позиції з відкритими очима } & \multicolumn{2}{c}{ В позиції з закритими очима } \\
\cline { 2 - 5 } & До АДВ & Після АДВ & До АДВ & Після АДВ \\
\hline ВСП & $\mathrm{U}=17^{* *}$ & $\mathrm{U}=18,5^{* *}$ & $\mathrm{U}=14,5^{*}$ & $\mathrm{U}=15,5^{*}$ \\
\hline ВФП & $\mathrm{U}=34,5^{* * *}$ & $\mathrm{U}=44,5^{* * *}$ & $\mathrm{U}=27^{* * *}$ & $\mathrm{U}=14,5^{*}$ \\
\hline $\mathrm{CB}$ & $\mathrm{U}=16^{* *}$ & $\mathrm{U}=24^{* * *}$ & $\mathrm{U}=19^{* *}$ & $\mathrm{U}=37,5^{* * *}$ \\
\hline
\end{tabular}

${ }^{*} \mathrm{p} \leq 0,01 ; * * \mathrm{*} \leq 0,05 ; * * * \mathrm{p}>0,05$

Перспективи подальших досліджень.

Дослідження є фрагментом дисертаційної наукової роботи та науково-дослідної роботи кафедри. Продовжується обстеження пацієнтів та вивчення особливостей ПБ у пацієнтів з ДД, їх значення під час створення реабілітаційних програм.
Ключові слова: постуральний баланс, стабілометрія, деформуючі дорсопатії, шийний відділ хребта, біль.

Конфлікт інтересів: Автори заявляють про відсутність конфлікту інтересів. 